Pesq. Vet. Bras. 35(11):889-892, novembro 2015 DOI: $10.1590 / \mathrm{S} 0100-736 \mathrm{X} 2015001100003$

\title{
Clinical and blood gasometric parameters during Vaquejada competition $^{1}$
}

\author{
Silvana S.B. Arruda², Lucio N. Huaixan², André R.C. Barreto-Vianna², Roberta F. \\ Godoy $^{3}$ and Eduardo M.M. Lima ${ }^{2 *}$
}

\begin{abstract}
Arruda S.S.B., Huaixan L.N., Barreto-Vianna A.R.C., Godoy R.F. \& Lima E.M.M. 2015. Clinical and blood gasometric parameters during Vaquejada competition. Pesquisa Veterinária Brasileira 35(11):889-892. Faculdade de Agronomia e Medicina Veterinária, Universidade de Brasília, Campus Universitário Darcy Ribeiro, Cx. Postal 4508, Brasília, DF 70910-970, Brazil. E-mail: limaemm@unb.br

Clinical and complementary analysis are good alternatives to evaluate physiological demand in performance horses. The aim of this study was to assess whether the physical effort variation of the three-day Vaquejada competition (a Brazilian form of bullfighting) reflected in clinical and blood gasometric changes. During the competition eight sprints have been performed on the first day (D1), eight on the second (D2) and three on the last one (D3). Ten horses were evaluated by checking heart and respiratory rates and collecting blood samples for use in portable chemistry analyzer. Through that, it was assessed potential of hydrogen ion $(\mathrm{pH})$, carbon dioxide pressure $\left(\mathrm{pCO}_{2}\right)$, bicarbonate $\left(\mathrm{HCO}_{3}-\right)$ and titratable base concentration (cBase). Evaluations were carried with resting of at least twenty hours, before physical activity (D0), as control parameter, and up to thirty minutes after each sprint. Clinical parameters have increased on D1, D2 and D3, when compared to D0, which demonstrated the increased demand for substrate and oxygen to the cells.. Blood gasometric trial showed reductions of all variables, most marked between D1 and D2. It was verified less alteration of all clinical and blood gasometric parameters in D3 against D0. We concluded that the change effort between days of competition influenced the clinical and blood gas parameters, demonstrating appropriate physiological response. The data were presented as mean and standard error of the mean (mean \pm SEM) obtained in different days. Normality was confirmed by the Kolmogorov-Sminov test and data were compared by one-way ANOVA, followed by post-test Holm-Sidak (GraphPad Prism 2.6 for Windows, GraphPad Software, San Diego, CA, USA). $\mathrm{P} \leq 0.05$ was considered as statistically significant.
\end{abstract}

INDEX TERMS: Acid-base balance, exercise, gasometry, horses.

RESUMO.- [Parâmetros clínicos e hemogasométricos de equinos durante prova de vaquejada.] As análises clínica e complementar são boas alternativas para avaliar a demanda fisiológica de equinos atletas. 0 objetivo deste estudo foi avaliar se a variação do esforço entre os três dias de competição de vaquejada refletiu em alterações clínicas e hemogasométricas. Durante a competição foram realizados oito sprints no primeiro dia (D1), oito no segundo (D2)

\footnotetext{
${ }^{1}$ Received on May 26, 2015.

Accepted for publication on November 13, 2015.

${ }^{2}$ Faculdade de Agronomia e Medicina Veterinária, Universidade de Brasília (UnB), Campus Universitário Darcy Ribeiro, Cx. Postal 4508, Brasília, DF 70910-970, Brazil. *Corresponding author: limaemm@unb.br

${ }^{3}$ Institute of Orthopaedics and Musculoskeletal Science, National Orthopaedics Hospital, University College of London, London, UK.
}

e três no ultimo (D3). Dez equinos foram avaliados através de aferição das frequências cardíaca, frequência respiratória e coleta de amostra de sangue para uso em analisador químico portátil. Foi determinado o potencial hidrogênionico $(\mathrm{pH})$, pressão de dióxido de carbono $\left(\mathrm{pCO}_{2}\right)$, bicarbonato $\left(\mathrm{HCO}_{3}^{-}\right)$e concentração de base titulável (cBASE). As avaliações foram realizadas em repouso de pelo menos vinte horas, antes do exercício (D0), considerado como parâmetro de controle, e até três minutos após cada sprint. Os parâmetros clínicos aumentaram em D1, D2 e D3, quando comparados a D0, o que demonstrou a maior demanda de substrato e oxigênio para as células. A avaliação hemogasométrica demonstrou redução de todas as variáveis, mais acentuada entre D1 e D2. Em D3, verificou-se menor alteração de todos os parâmetros clínicos e hemogasométricos 
em comparação a D0. Foi possível concluir que a variação de esforço entre os dias de competição influenciou os parâmetros clínicos e hemogasométricos, demonstrando resposta fisiológica adequada. Os dados foram apresentados como média e erro padrão da média (mean \pm SEM) obtidos nos diferentes dias. A normalidade foi comprovada pelo teste de Kolmogorov-Sminov e dados foram comparados através do teste one-way ANOVA, seguido pelo pós-teste de Holm-Sidak (GraphPad Prism 6.02 for Windows, GraphPad Software, San Diego, CA, USA). Foi considerado $p \leq 0.05$, como estatisticamente significativo.

TERMOS DE INDEXAÇÃO: Equilíbrio ácido-base, exercício, gasometria, equinos.

\section{INTRODUCTION}

Equine ability to athletic activities, characterized by high intensity exercises, is due to increment mechanisms of cardiovascular and respiratory responses, primarily affecting blood flow, providing oxygen and substrate to the cells that enhance the metabolism. It is also necessary to reach the acid-base balance through a series of biochemical and physicochemical reactions associated to anaerobic energy production. The body reacts in different ways, depending on the challenge posed by the exercise, as shown by Ferraz et al. (2010), they found that after exercise of high handicap polo horses, reduction in hydrogenionic potential, carbon dioxide pressure and bicarbonate, and Di Filippo et al. (2009), which observed different response, with increase in these parameters after $60 \mathrm{~km}$ in endurance horses. Therefore, the physical activity performance involves changes of various organic systems (Bayly et al. 2006).

The Vaquejada submits animals to varied conditions of which the training is consisted. Vaquejada physical activities are of vigorous intensity and short duration (Lopes et al. 2009). The effort promoted by three consecutive days of intense activity, under supply out of the routine of water and food can reflect in physical, biochemical and hematological disorders (Lopes et al. 2009), which makes the clinical and complementary tests extremely useful to measure the physiological demand during this sport activity (Balogh et al. 2001).

However, there is limited information on these changes, especially taking into account the degree of effort spent at different days. Most of vaquejada competitions, there is no limit to the number of sprints. Usually the horse owner who decides how often the animal will compete on each day. Thus, the body of the animal is challenged differently between days which should cause changes in physiologic demand and response. The objective of this study was to determine whether the change in the magnitude of the efforts that the horses were submitted between three days of vaquejada of competition, characterized by different number of sprints each day, on heart and respiratory rates, hydrogen potential $(\mathrm{pH})$, carbon dioxide pressure $\left(\mathrm{pCO}_{2}\right)$, bicarbonate $\left(\mathrm{HCO}_{3}^{-}\right)$ and concentration of titratable base (cBase).

\section{MATERIALS AND METHODS}

Ten male geldings horses (is the category that most present in the competition), were assessed, which were seven to ten years old, athlete (three horses were seven years old, the other three had eight years, two with nine years and two with ten years) of Vaquejada competition. Only male animals were chosen to prevent that the hormonal cycle of females influence the results. The animals were housed in the João Coragem Stud Farm (Brasília, Distrito Federal, Brazil) at $15^{\circ} 46^{\prime} 48^{\prime \prime}$ South latitude, 47 $55^{\prime} 45^{\prime \prime}$ West longitude and average altitude of $1,130 \mathrm{~m}$, in which the competition " $3^{\text {a }}$ Vaquejada Parque João Coragem" took place. The local Ethics Committee on Animal Use from the Universidade de Brasília (University of Brasília) approved the study (\# 68388/2013).

Twenty assessments were performed along four different days. The first was carried seven days before competition to check animal conditions before the activities, used as a control parameter or day zero (D0). Subsequently, animals were evaluated within 3 minutes after each sprint. Each sprint lasted approximately 10 seconds, and on each day of competition, all ten horses performed the following amounts of sprints:

Day one (D1), first day of competition with eight sprints;

Day two (D2), the second day of competition with eight sprints,

Day three (D3), the third day of competition with three sprints.

The interval between each sprint was about 15 minutes.

In D0, it was conducted thorough clinical examination, collecting $4 \mathrm{ml}$ of blood from the left jugular vein for hemogram in veterinary hematology counter (PocH-100iVDiff $®$, Sysmex, Brazil) and determination through portable chemistry analyzer (i-STAT $®$, CG8+ cartridge) of the hydrogen potential $(\mathrm{pH})$, carbon dioxide pressure ( $\mathrm{pCO} 2)$, bicarbonate $\left(\mathrm{HCO}_{3}{ }^{-}\right)$and the concentration of titratable bases (cBase). Moreover, it was performed measurements of heart and respiratory rates, with stethoscope, and blood from left jugular vein for use in portable chemistry analyzer.

Data were presented as mean and standard error mean (mean \pm SEM) from the three different days. Normality was tested by Kolmogorov-Sminov and data were compared through one-way ANOVA test, followed by Holm-Sidak test using GraphPad Prism 6.02 for Windows (GraphPad Software, San Diego, CA, USA). It was considered $P \leq 0.05$, as statistically significant.

\section{RESULTS}

The ambient conditions were evaluated at all different time of the tests and their averages are shown in Table 1. As observed, the ambient temperature and relative humidity ranged among days, with most notable difference in D2, that environmental variation does not seem to have influenced the analyzes performed on the animals, since no differences were observed among the same sprints on different days (Fig.1).

Concerning clinical parameters (Table 1), heart rate (HR) increased substantially in D1 compared with D0 $(\mathrm{p}=<0.0001)$ and decreased in D2 and D3 $(\mathrm{p}=<0.0001)$, comparing with D1. Respiratory rate (RR) raised in D1, remaining at the same level in D2, when compared with D0 $(p=<0.0001)$, and reduced in D3, against D1 and D2. Addionally, $\mathrm{pH}, \mathrm{pCO}_{2}, \mathrm{HCO}_{3}^{-}$and cBase (Table 1) decreased $(p<0.0001)$ from D1; however, on D3, it was less sharp compared with D1 and D2 $(\mathrm{p}<0.0001)$.

Comparing among the same sprints on different days, we found no difference in the parameters analyzed (Fig.1), indicating that the rest period between the days of competition was sufficient to restore the parameters altered by exercise. 
Table 1. Heart rate, respiratory rate, $\mathrm{pH}, \mathrm{pCO} 2, \mathrm{HCO}-$ and concentration of titratable bases (cBase). The values represent mean \pm standard error mean, $\mathrm{n}=\mathbf{1 0}$ per group, $\mathrm{p} \leq \mathbf{0 . 0 5}$ when comparing D0, D1, D2 and D3 (one-way ANOVA and Holm-Sidak test)

\begin{tabular}{lcccc}
\hline & D0 & D1 & D2 & D3 \\
\hline Ambient temperature $\left({ }^{\circ} \mathrm{C}\right)$ & $24.46 \pm 2.76 \mathrm{a}$ & $21.08 \pm 0.68 \mathrm{ac}$ & $31.17 \pm 5.30 \mathrm{~b}$ & $18.38 \pm 1.54 \mathrm{c}$ \\
Relative humidity $(\%)$ & $54.20 \pm 8.61 \mathrm{ac}$ & $65.3 \pm 2.18 \mathrm{a}$ & $30.54 \pm 2.32 \mathrm{~b}$ & $46.5 \pm 1.57 \mathrm{c}$ \\
$\mathrm{HR}(\mathrm{bpm})$ & $39,20 \pm 1,02 \mathrm{a}$ & $111,8 \pm 3,75 \mathrm{~b}$ & $100,4 \pm 3,1 \mathrm{c}$ & $89,87 \pm 3,04 \mathrm{~d}$ \\
$\mathrm{RR}(\mathrm{mpm})$ & $20 \pm 2,82 \mathrm{a}$ & $61,17 \pm 2,26 \mathrm{~b}$ & $63,38 \pm 2,41 \mathrm{~b}$ & $53,73 \pm 1,7 \mathrm{c}$ \\
$\mathrm{pH}$ & $7,42 \pm 0,0 \mathrm{a}$ & $7,19 \pm 0,02 \mathrm{~b}$ & $7,19 \pm 0,01 \mathrm{~b}$ & $7,27 \pm 0,02 \mathrm{c}$ \\
$\mathrm{pCO}_{2}(\mathrm{mmHg})$ & $45 \pm 1,42 \mathrm{a}$ & $36,58 \pm 2,02 \mathrm{~b}$ & $35,5 \pm 1,38 \mathrm{~b}$ & $40,75 \pm 1,34 \mathrm{a}, \mathrm{b}$ \\
$\mathrm{HCO}_{3}-(\mathrm{mmol} / \mathrm{L})$ & $29,66 \pm 0,97 \mathrm{a}$ & $14,14 \pm 0,68 \mathrm{~b}$ & $13,89 \pm 0,64 \mathrm{~b}$ & $19,62 \pm 1 \mathrm{c}$ \\
$\mathrm{cBASE}^{-140}$ & $5,2 \pm 1,06 \mathrm{a}$ & $-14 \pm 0,94 \mathrm{~b}$ & $-14,25 \pm 0,81 \mathrm{~b}$ & $-7,06 \pm 1,14 \mathrm{c}$
\end{tabular}

Heart rate (HR) in beat per minute, respiratory rate (RR) in respiratory movements per minute, hydrogen potential $(\mathrm{pH})$, carbon dioxide pressure $\left(\mathrm{pCO}_{2}\right)$, bicarbonate $\left(\mathrm{HCO}_{3}^{-}\right)$and concentration of titratable rate (cBase) of Vaquejada horses before physical activity (D0), after the first (D1), second (D2) and third day of competition (D3). a-d Different letters in the same line indicate statistical difference $(\mathrm{p}<0.05)$.
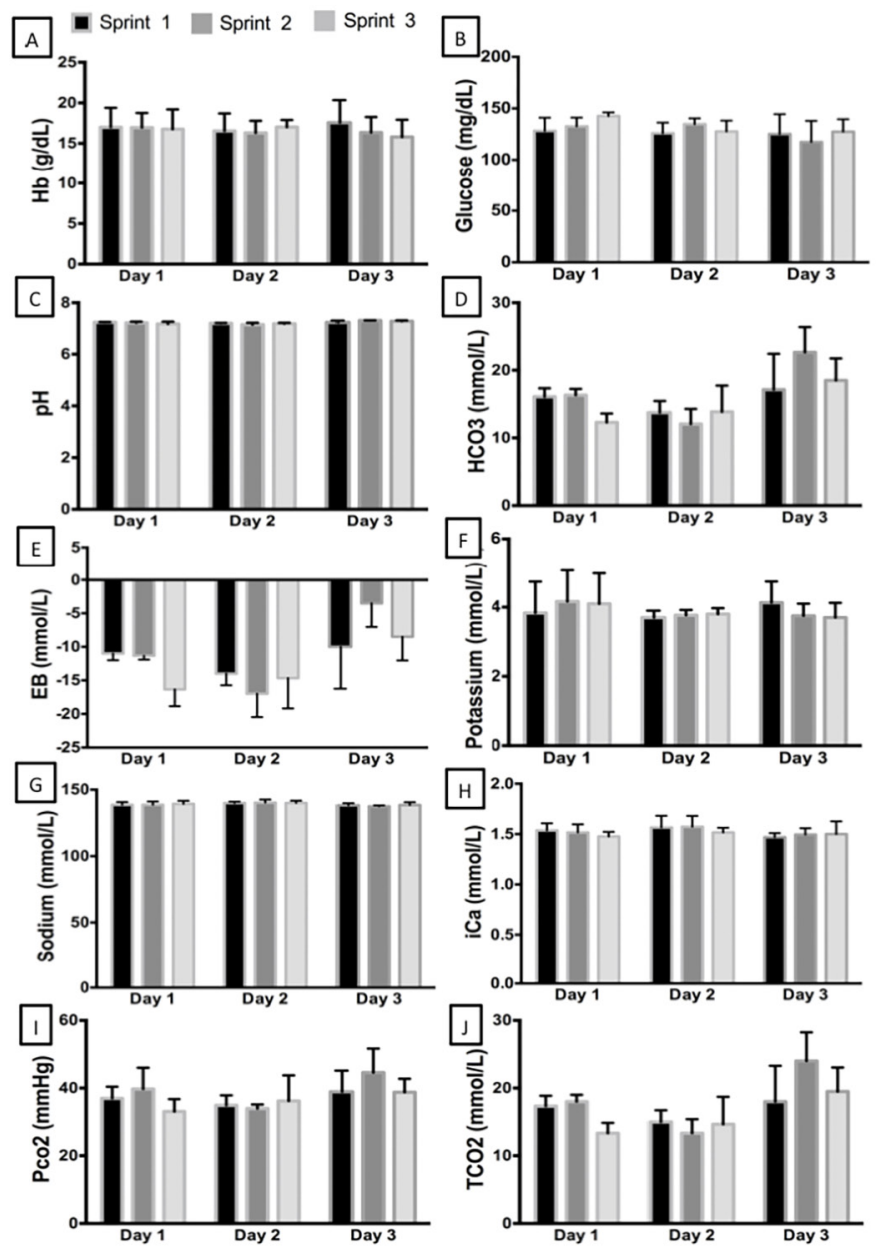

Fig.1. Analysis of parameters among the same sprints on different days during vaquejada competition. A) Hb; B) glucose; C) $\mathrm{pH}$; D) HCO3; E) EB; F) Potassium; G) Sodium; H) iCa; I) PCO2; J) TCO2.

\section{DISCUSSION}

Exercise effort brings forth substantial increase in flow of substrates to cells and oxygen supply, which is reached by increasing gas exchanges and respiratory frequency raise (Hinchcliff et al. 2002). In addition, increased blood supply to tis- sues, which is regulated by heart rate (Piccione et al. 2013). Thus, as observed in the present study, there was an increase of $185 \%$ in heart rate in $\mathrm{D} 1$, and $217 \%$ in respiratory rate in D2, when compared to the evaluation before exercise (D0). Moreover, 29\% reduction in HR in D3 over D2 possibly was related to animal individuality to respond to stress. Since in D3, animals showed a more effective cardiovascular response. Such fact suggests that this prepared or activated compensation is functionally related to demanded efforts of the other days, that is, therefore, animals have adapted themselves. The cardiac and respiratory rates were evaluated exactly 3 minutes after exercise, this has allowed us to ensure that all animals have the same time to recovery the frequencies, this standardization was adopted because we did not have the possibility to measure the real frequencies, that is, the cardiac and respiratory frequencies during the race.

In contrast, it was observed in D3 a lower demand when considering the effort, bearing in mind that at this day, it was performed a few number of sprints, reducing $29 \% \mathrm{HR}$ and $49 \%$ RR comparing with D2. Maybe, it might have occurred less demand for substrate and oxygen supply in D3 when compared to the first days.

High intensity activity performed by animals in Vaquejada competition resulted in increased intramuscular production of carbon dioxide (CO2), corroborating results of Ferraz et al. (2010), which mainly influenced respiratory rate in D1 and D2 and presented hyperventilation to compensate and reduce the elevated $\mathrm{CO} 2$ concentration.

Ferraz et al. (2010) observed that after exercising, there is a reduction in $\mathrm{pH}, \mathrm{pCO} 2, \mathrm{HCO}-$ of high handicap polo horses, such as observed in the current study, what indicates the similarity of the two categories.

It was evidenced by $\mathrm{pH}$ evaluation a reduction of $3 \%$ in D1 and 2\% in D3 when comparing to D0. The most part of carbon dioxide produced by muscles during the physical activity was converted into carbonic acid (H2CO3), which spread in the bloodstream and dissociated in hydrogen $(\mathrm{H}+)$ and bicarbonate ( $\left.\mathrm{HCO}^{-}\right)$ions. The respiratory system may have increased CO2 removal rate in D1 and D3, and its conversion to HCO3- could not be completed, as reported by Fazio et al. (2012). Thus, it was possible to explain the 
pCO2 reductions of $19 \%$ and $9.5 \%$ in D1 and D3. Additionally, it was achievable to justify $\mathrm{HCO}_{3}$ - decreases of $66.1 \%$ in D1 and 33.8\% in D3, related to D0. The lack of statistical difference between D1 and D2 might have be related to needless increment for respiratory compensation, having in mind that $\mathrm{pCO}_{2}$ and $\mathrm{HCO}$ - followed $\mathrm{pH}$ changes and had no alterations on those days.

Blood base production was quantified by cBase (Viu et al. 2010) establishing metabolic acidosis by the reduction of 370\% in D1 and 237\% in D3, with no statistical difference between D1 and D2. This result was consistent with the findings for other parameters concerning acid-base status of these days. The more negative the values (D1 and D2), the greater the degree of metabolic acidosis, with some decrease in D3, which has followed other variables related to the acid-base status.

It can therefore be assumed that in vaquejada activity, metabolic acidosis was detected by reduction in $\mathrm{pH}, \mathrm{pCO}_{2}$, $\mathrm{HCO}_{3}$ - and cBase, as observed by Ferraz et al. (2010). Metabolic acidosis has relationship with lactic acid diffusion, which is produced by muscle cells and goes into the bloodstream [9]. However, most authors did not attribute acidosis to lactic acid, but to release of protons $(\mathrm{H}+)$ during ATP hydrolysis, since it occurs markedly in high-intensity exercises (Ferraz et al. 2010, Robergs \& Parker 2011, Boning \& Maasen 2008), as well as it happens for horses in Vaquejada competition.

It is possible to hypothesize that, effort level alterations along days promoted higher degree of metabolic acidosis, which comes from the $\mathrm{pH}, \mathrm{pCO}_{2}, \mathrm{HCO}_{3}$ - e cBase reductions on the first day of the competition, remaining on D2 and decreasing on the last day. On D3, the animals performed less effort due to reduction on sprint number (three) and less ATP spend with reduction in proton release against D1 and D2 (eight sprints).

The more effort on the first and second days of competition produced a greater change in clinical and blood gasometric parameters of competitors. By decreasing the number of sprints on the last day and consequent reduction in physical effort, the animals had non-marked responses. Thus, effort variation reflected in daily changes of clinical and blood gasometric parameters. This suggests that, despite the harsh conditions encountered during the competition, the animals were adapted and physiological response were satisfactory in every day, demonstrating increase in clinical parameters and reduced blood gas levels when the effort was considered greater, that is, in the days when horses effected highest number of sprints.

\section{REFERENCES}

Balogh N., Gaál T. \& Petri A. 2001. Biochemical and antioxidant changes in plasma and erythrocytes of Pentathlon horses before and after exercise. Vet. Clin. Pathol. 30:214-218.

Bayly W.M., Kingston J.K. Brown J.A., Keegan R.D., Greene S.A. \& Slides R.H. 2006 Changes in arterial, mixed venous and intraerythrocytic concentrations of ions supramaximally exercising horses. Equine Vet. J. 36:294297.

Boning D. \& Maasen N. 2008. Last word on point: counterpoint: lactic acid is/is not the only physicochemical contributor to the acidosis of exercise. J. Appl. Physiol. 105:369.

Fazio F., Messina V., Casella S., Giannetto C., Marafioti S. \& Piccione G. 2012. Effect of a simulate show jumping competition on the blood gas profile of horses trained for show jumping. Turk. J. Vet. Anim. Sci. 36:259-265.

Ferraz G.C., Soares O.A.B., Foz N.S.B., Pereira M.C. \& Queiroz-Neto A. 2010. The workload and plasma ion concentration in a training match session of high-goal (elite) polo ponies. Equine Vet. J. 38:191-195.

Hinchcliff K.W., Lauderdale M.A., Dutson J., Geor J., Lacombe V.A. \& Taylorm L.E. 2002. High intensity exercise conditioning increases accumulated oxygen deficit of horses. Equine Vet. J. 34:9-16.

Lopes K.R.F., Batista S., Dias R.V.C. \& Sato-Blanco B. 2009. Influence of "Vaquejada" competitions on stress parameters in equines. Ciênc. Anim. Bras. 10:538-543.

Piccione G., Messina V., Bazzano M., Gianetto C. \& Fazio F. 2013. Heart Rate, Net Cost of Transport, and Metabolic Power in Horse Subjected to Different Physical Exercises. J. Equine Vet. Sci. 33:586-589.

Robergs R.A. \& Parker D. 2011. The wandering argument favoring a lactic acidosis. Am. J. Physiol. 291:238-239.

Viu J., Jose-Cunilleras E., Armengou L., Cesarini C., Taracón I., Rios J. \& Monreal L. 2010. Acid-base imbalances during a $120 \mathrm{~km}$ endurance race compared by traditional and simplified strong íon difference methods. Equine Vet. J. 38:76-82.

Watanabe M.J., Thomassian A., Teixeira-Neto F.J., Alves A.L.G., Hussni C.A. \& Nicoletti J.L.M. 2006. Changes in arterial pH, PO2, PCO2 and blood lactate concentration in Arabian horses during exercise on a high-speed treadmill. Arq. Bras. Med. Vet. Zootec. 58:320-326. 